\title{
TREND ANALYSIS OF RAINFALL-RUNOFF REGIMES IN SELECTED HEADWATER AREAS OF THE CZECH REPUBLIC
}

\author{
ZDENĚK KLIMENT ${ }^{1)}$, MILADA MATOUŠKOVÁ ${ }^{1)}$, ONDŘEJ LEDVINKA ${ }^{2)}$, \\ VÁCLAV KRÁLOVEC ${ }^{1)}$ \\ ${ }^{1)}$ Katedra fyzické geografie a geoekologie Př́rodovědecké fakulty Univerzity Karlovy, Albertov 6, 12843 Praha 2, \\ Česká republika; Mailto: kliment@natur.cuni.cz \\ ${ }^{2}$ Český hydrometeorologický ústav, pobočka Praha, Na Šabatce 17, 14306 Praha 4-Komořany a Ústav aplikací matematiky \\ a výpočetní techniky Př́rodovědecké fakulty Univerzity Karlovy, Albertov 6, 12843 Praha 2, Česká republika.
}

The main aim of this work is to evaluate the development of rainfall-runoff regime in selected river basins of the Šumava Mountains (Bohemian Forest), the Jeseníky Mountains and the Krušné Mountains (Ore Mountains) in the last 50 years. Besides the identification of inhomogeneity in time series of mean discharges, rainfall amounts, temperature and snow cover data, the work deals with an analysis of trends using annual and monthly data. Different methodological tools for identification of changes and trends in hydro-climatic time series have been introduced in this study, especially different methods of statistic testing and an application of Mann-Kendall seasonal test. The results have been compared not only from the point of view of the methods applied here, but as well from the viewpoint of geographical difference of the mentioned areas.

KEY WORDS: Statistics, Trends, Rainfall-Runoff Regime, Air Temperature, Snow Parameters, Headwaters Areas, Czech Republic.

Zdeněk Kliment, Milada Matoušková, Ondřej Ledvinka, Václav Královec: ANALÝZA TRENDŮ SRÁŽKO-ODTOKOVÉHO REŽIMU VE VYBRANÝCH PRAMENNÝCH OBLASTECH ČESKÉ REPUBLIKY. J. Hydrol. Hydromech., 59, 2011, 1; 53 lit., 9 obr., 5 tab.

Hlavním cílem předložené studie je zhodnotit vývoj srážko-odtokového režimu ve vybraných povodích v oblasti Šumavy, Jeseníků a Krušných hor za posledních 50 let. Vedle zjišstování nehomogenit v časových řadách průměrných průtokových, srážkových, ale i teplotních a sněhových dat se práce zabývá analýzou trendů na úrovni ročních hodnot a jednotlivých měsíců. $V$ práci jsou představeny různé metodické nástroje ke sledování změn a trendů v hydroklimatologických řadách, zejména různé metody statistického testování a aplikace Mann-Kendallova sezónního testu. Výsledky jsou porovnány nejen z hlediska použitých metod, ale i geografické rozdílnosti sledovaných území.

KLÍČOVÁ SLOVA: statistika, trendy, srážko-odtokový režim, teplota vzduchu, sněhové charakteristiky, pramenné oblasti, Česká republika.

\section{Introduction}

Analyses of trends in long-term series of hydrological and meteorological data are thought to be an important tool for detection and understanding of changes in a rainfall-runoff process. Their results appropriately support findings of forecasting models and are exploitable in water management planning and also as a flood-protection. Climatic changes, together with a different type and stage of human impact, are considered to be the main causes of rainfall-runoff changes. There are not supposed to be any significant changes in the total volume of rainfall with relation to global warming in the Czech Republic, but more significant changes are expected in the time distribution of rainfall: precipitation decrease in April, August and September and precipitation increase in October and winter months (Kalvová et al., 2002). According to Kubát (2007), there will be a decrease in a total annual runoff. During winter months, a runoff increase is expected only if precipitation is not stored in a snow cover, but it flows directly away. Also the change in flood-frequency is expected (more frequent winter floods, an increase in a number of local floods). Some predicted phenomena are even possible to be 
monitored these days (Kliment, Matoušková, 2008; Fiala, 2008). There are commonly discussed land cover changes effects and land use effects (Blažková, Kolářová, 1994; Klöcking, Haberlandt, 2002; Huang et al., 2003; Wu et al., 2007; Chaves et al., 2008), land drainage effects (Švihla et al., 1992; Doležal et al., 2004), effects of water reservoirs building, urban areas, mining and industry and stream regulations (Meyer, 2001; Kř́ž, 2003; Czaja, $2005)$ in the sense of direct influence of runoff. Some of recent pilot projects deal with changes in land use planning together with climatic changes (Juckem et al., 2008; Huo et al., 2008; Zhang et al., 2008). Setting a limit for each of the runoff influencing factors under changeable conditions is a very difficult task to be solved (Samaniego, Bardossy, 2005). Different methods are used for the analysis of runoff trend. General ways of changes detection were described clearly by Kundzewicz and Robson (2004). A pilot project by Kaňok (1997) could be regarded as a methodical tool from a viewpoint of detection of runoff changes caused by anthropogenous influence. Particular examples of trend analyses in rainfall-runoff time series are brought in recent projects from different parts of the world (Domonkos, Piotrowicz, 1998; Pekárová, 2003; Burn et al., 2004; Falarz, 2004; Fu et al., 2004; Franke et al., 2004; Birsan et al., 2005; Majerčáková et al., 2007; Chen et al., 2007; Bae et al. 2008; Pekárová et al., 2008; Trömel, Schönweise, 2008; $M a$ et al., 2009; Schöner et al., 2009 and others).

The submitted research deals with the identification of inhomogeneity in time series and with trend analysis of rainfall-runoff regimes in selected headwater areas of the Czech Republic in the Šumava Mountains, the Jeseníky Mountains and the Krušné Mountains. These are the areas where recent disasterous floods (the years 1997 and 2002) took place. The work summarize results and links up with earlier research projects, especially $\mathrm{VaV}$ $\mathrm{SM} / 2 / 57 / 05$ "Long-term changes of river ecosystems in floodplains affected by extreme floods" and MSM 0021620831 "Geographical systems and risk processes in the context of global changes and European integration". The main aim is to introduce different methodical tools for observing trends and changes in the development of rainfall-runoff relations. Another important goal is to compare and try to clarify results not only from the point of view of the methods applied here, but as well from the viewpoint of geographical differences of studied areas.

\section{Methodology and source data}

The methodological part includes analytic approaches and synthesis. The analytic approaches are aimed at analysis of rainfall-runoff regimes supplied by an analysis of temperature and snow conditions. The methods applied in the research are the following ones: the method of simple and double mass curves of precipitation and runoff data (Kliment, Matoušková, 2005) and mainly testing methods that include the testing of time series homogeneity, the identification of inhomogeneity in time series, and statistic tools for trend analysis. Absolute homogeneity has been tested for all time series of discharge, precipitation, air temperature and snow data monthly, seasonally and yearly. A nonparametric Pettitt test (Pettitt-Mann-Whitney test) was chosen as the basic one for evaluation of precipitation and discharge data. This approach enables to detect any significant change of a mean value in time series when the exact time is unknown (Kundzewicz, Robson, 2004). A parametric SNHT (Standard Normal Homogeneity Test), developed by Alexandersson, using AnClim software, that identifies a sudden change in a mean value of time series (Štěpánek, 2004), has been applied to air temperature and snow data. The others so called "sequence" tests have been applied to alternative confirmation or disapproval of identified year of breaking homogeneity. These are: non-parametric Wilcoxon (Mann-Whitney) test and Kruskal-Wallis test in SPSS software. The presence of known dividing line in time series is tested (Anděl, 1998). Besides the tests mentioned above, a von Neumann test has been applied to precipitation data (Kaňok, 1997). The same significance level of 0.05 has been set for all of the tests. In the tests of relative homogeneity there have been compared time series of uncertain homogeneity with one or more time series of verified homogeneity. Besides Alexandersson's homogeneity test for a simple break-point in the environment of AnClim software (Štěpánek, 2004), Wilcoxon test of simple and pair variation has been used.

The evaluation of a trend in time series of hydrological and climatic phenomena has been done using a seasonal non-parametric Mann-Kendall test (Helsel, Frans, 2006; Libiseller, 2004; Kliment, Matoušková, 2009) in MS Excel software supported by Anders Grimvall and Claudia Libiseller macro. This test is used widely and can deal with missing and distant data. The test has two parameters important for the trend detection: a significance level 
(p), which represents the power of the test, and a slope magnitude estimate (MK-S), which represents the direction and volume of the trend. The trends in time series were completed by a calculation of Kendall coefficient of sequential correlation $\tau$ (Mann, 1945; Kendall, 1975; Fu et al., 2004). The method of orographic interpolation (Šercl, Lett, 2004) has been used for a calculation of areal precipitation in a river basin. Individual attention in the relation to runoff has been paid to the occurrence and frequency of higher water events (more 1-year water level), to monitoring of a trend in the development of mean air temperature and snow conditions (number of days with snow cover, average snow cover depth) on the basis of 5-year moving averages. The data from CHMI (Czech Hydrometeorological Institute) has been used in the analyses. The data represent annual, monthly or daily figures: discharge data for closing profiles of selected basins since the beginning of measurements till the year 2008 (i.e. for the last 60 years), precipitation for climatic stations in the period of 1961-2008, air temperature data and snow cover data for selected climatic stations in the period of 1961-2008. In the final synthesis, findings about discovered trends in rainfall-runoff regime have been compared with land use and land cover changes and with the intensity of amelioration. The following materials served as the background data sources: database of longterm changes in land use according to the land register (Bičik et al., 2003), CORINE database of Land cover for the years 1990 and 2000, or an interpretation of satellite air photos (Hais, 2003; Hintnaus, 2008). The database of stream regulations and land drainage was provided by AWMA (Agricultural Water Management Authority) in the scale of $1: 10000$.

\subsection{Delimitation and basic characteristics of model river basins}

Six river basins (Fig. 1) have been included in this work. In the headwater area of the Šmava Mountains there are river basins of the Vydra, the Ostružná and the upper reach of the Blanice River. In the Jeseníky Mountains there are found upper reaches of the Opava and the Opavice. Finally, the Krušné Mountains are represented by the Rolava River basin (for more details see Tab. 1).

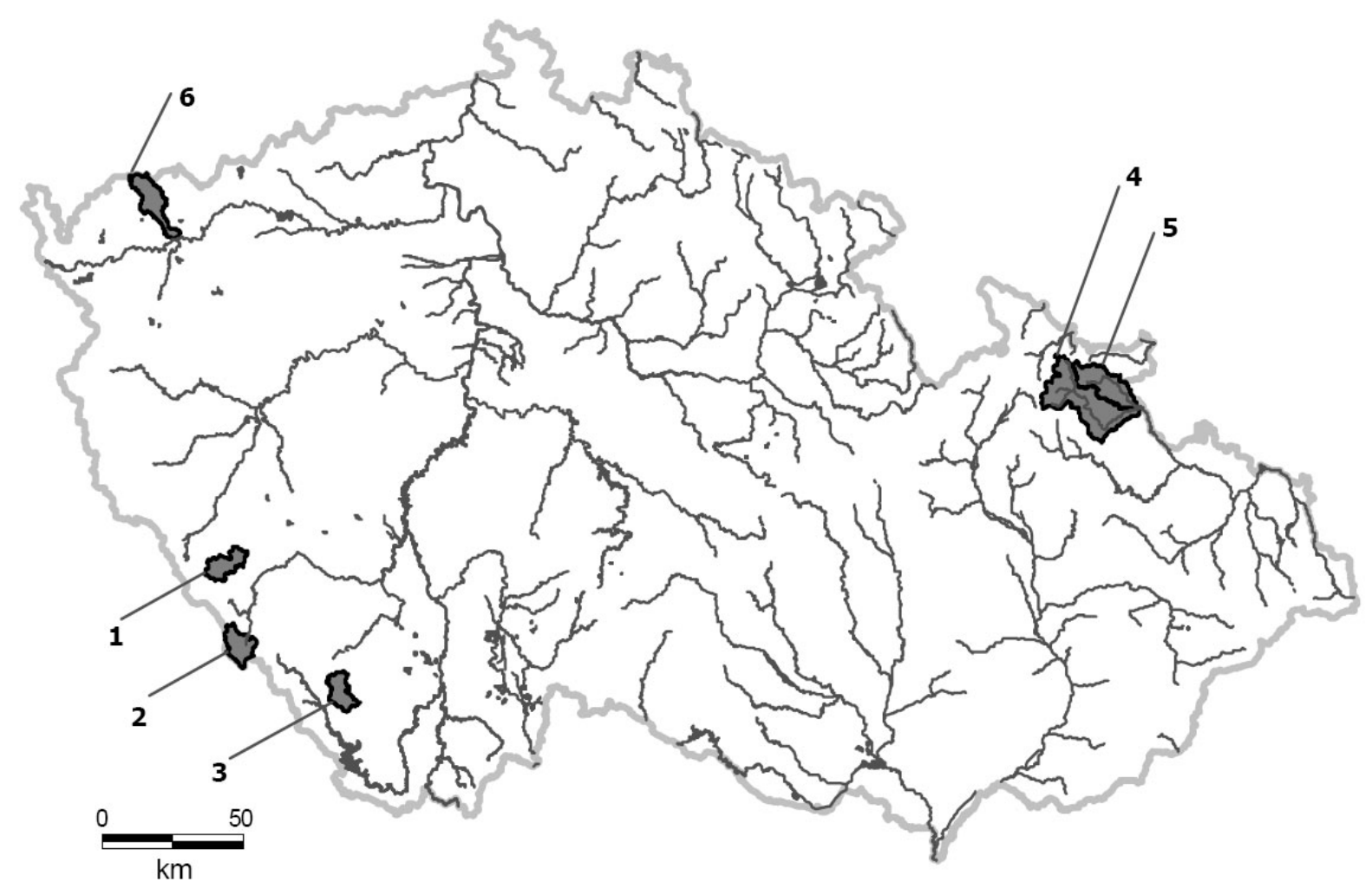

Fig. 1. Delimitation of study river basins in the Czech Republic; 1 - Ostružná basin, 2 - Vydra basin, 3 - Upper Blanice basin, 4 Upper Opava basin, 5 - Opavice basin, 6 - Rolava basin. 
Trend analysis of ranifall-runoff regimes in selected headwater areas of the Czech Republic

$\mathrm{T}$ a b 1 e 1. Basic characteristics of study river basins.

\begin{tabular}{|c|c|c|c|c|c|c|c|c|c|c|c|c|}
\hline $\mathrm{DBNr}$ & Gauging site & River & $\begin{array}{c}\text { Monitor. } \\
\text { from }\end{array}$ & $\begin{array}{c}A \\
{\left[\mathrm{~km}^{2]}\right.}\end{array}$ & $\begin{array}{c}P \\
{[\mathrm{~mm}]}\end{array}$ & $\underset{\left[\mathrm{m}^{3} \mathrm{~s}^{-1]}\right.}{Q_{a}}$ & $\begin{array}{c}\varphi \\
{[\%]}\end{array}$ & $\begin{array}{l}R_{\max } \\
{[\mathrm{m}]}\end{array}$ & $\begin{array}{l}R_{\min } \\
{[\mathrm{m}]}\end{array}$ & $\begin{array}{l}F A \\
{[\%]}\end{array}$ & $\begin{array}{l}A L \\
{[\%]}\end{array}$ & $\begin{array}{l}D A \\
{[\%]}\end{array}$ \\
\hline 1350 & Modrava & Vydra & 1931 & 93.41 & 1357 & 3.4 & 84.6 & 1373 & 935 & 59.1 & 0 & 0 \\
\hline 1390 & Kolinec & stružná & 1949 & 92.42 & 919 & 1.2 & 44.6 & 117 & 52 & 49.3 & 17.2 & 8.3 \\
\hline 1450 & Blanický Mlýn & & 1953 & 85.2 & 83 & 0.93 & 41 & 12 & & 64.3 & 0.3 & 5.3 \\
\hline 2101 & Stará Role & Rolav & 1968 & 125.34 & 950 & 2.39 & 63.3 & 1008 & 390 & 34.2 & 21.1 & \\
\hline 2630 & Krnov & Opava & 1953 & 370.5 & 850 & 4.06 & 40.7 & 1492 & 311 & 61.3 & 6.3 & 4.5 \\
\hline 2650 & Krnov & Opavice & 1953 & 175.52 & 776 & 1.37 & 31.7 & 974 & 311 & 41.8 & 17.2 & 4.2 \\
\hline
\end{tabular}

DBNr - database number, $A$ - area of a basin, $P$ - annual precipitation amount for a basin for the hydrological period 1962-2008, $Q_{a}$ - mean annual discharge from the beginning of measurement until year 2008, $\varphi$ - annual runoff coefficient for the period 1962 $-2008, R_{\max }$ and $R_{\min }$ - maximum and minimum altitude, $F A$ - forest area, $A L$ - arable land (CORINE, 2000), $D A-$ drained area (AWMA).

The river basins have been chosen regarding their location, data integrity of hydrometeorological series and results of previous research (Kliment, Matoušková, 2006; Ledvinka, 2008; Královec, 2009). They are significant for high mean annual precipitation, higher rate of specific outflow and runoff coefficient, a comparable size of the river basins and similar geologic and soil conditions, but different land cover and anthropogenous impacts. However, the river basins of the Vydra, upper Opava and upper Blanice represent natural environment with a high rate of afforestation. The river basins of the Opavice, Ostružná and Rolava are still represented by quite a high rate of arable land despite many attempts to grass the land over in the last 15 years. The level of stream modification and surface drainage vary, the most affected is the Ostružná River (see Fig. 2). Surface drainage has influenced almost $10 \%$ of the area of the river ba$\sin .20 .6 \%$ of the length of the river network has been regulated.

\section{Results}

\subsection{Analysis of rainfall-runoff relations using mass curve method}

A method of mass curves has already been used for the initial identification in time series of discharge and precipitation figures. A pattern of rainfall-

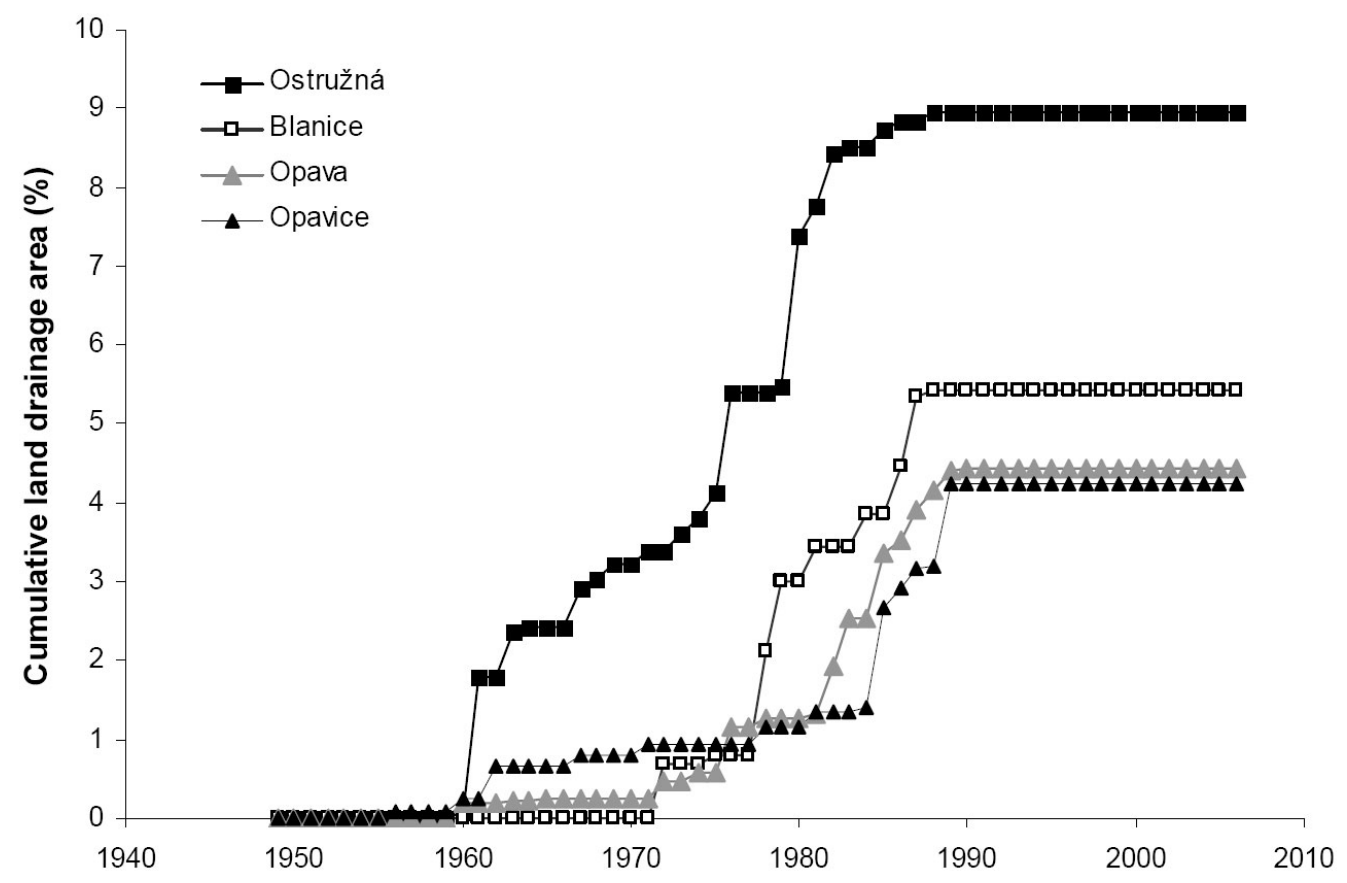

Fig. 2. Development of land drainage area in study basins (1949-2008). 
-runoff simple mass curves is thought to be a basis. Daily, monthly and yearly values can be used without a loss of any information. Changes are characterized by a directional deviation of runoff mass curve from rainfall mass curve which is mostly of linear character (Fig. 3). Double mass curves of annual discharges and precipitation have been processed for better understanding. Sections of a different development have been highlighted and smoothed to be clearly interpreted. The break points of mass curves have been supported by the years (Fig. 4). A significant period of a runoff increase is evident from the course of mass curves between the years 1974 and 1982. This period manifests itself in all of the monitored streams with the exception of the Vydra. The most considerable manifestation occurs in the river basins of Ostružná and Opavice. Then a short-term runoff increase is proved in the year 1997 in the Opava River basin and in the year 2002 in the Blanice River basin. A decreasing trend in runoff figures has been continuing since the beginning of the $80 \mathrm{~s}$ of the $20^{\text {th }}$ century till these days. Deviations in discharge series have been also verified by Wilcoxon nonparametric test. Evaluated data series have been delimitated regarding identified changes: 1967-1974, 1975-1982, 1983-1990, 1991-1998 and 1999-2006. The highest deviations of statistic significance have been recorded for the Ostružná in the period of increasing discharge from 1975 to $1982\left(\mathrm{~W}_{0.01}(8)=0\right)$, for the Blanice $\left(\mathrm{W}_{0.01}(8)=0\right)$ and the Opavice $\left(\mathrm{W}_{0.05}(8)=3\right)$ in the period of decreasing discharge in 1983-1990. There have been proved no deviations in the river basins of the $\mathrm{Vy}$ dra, the Rolava and the upper Opava. As the next step, double mass curves of annually measured and calculated discharges based on precipitation according to Searcy, Hardison (1960) have been applied. The method has not proved itself to be suitable when regarding the low values of correlation between measured values of precipitation and runoff. On the contrary with discharge series, there have been shown no significant deviations in rainfall series.

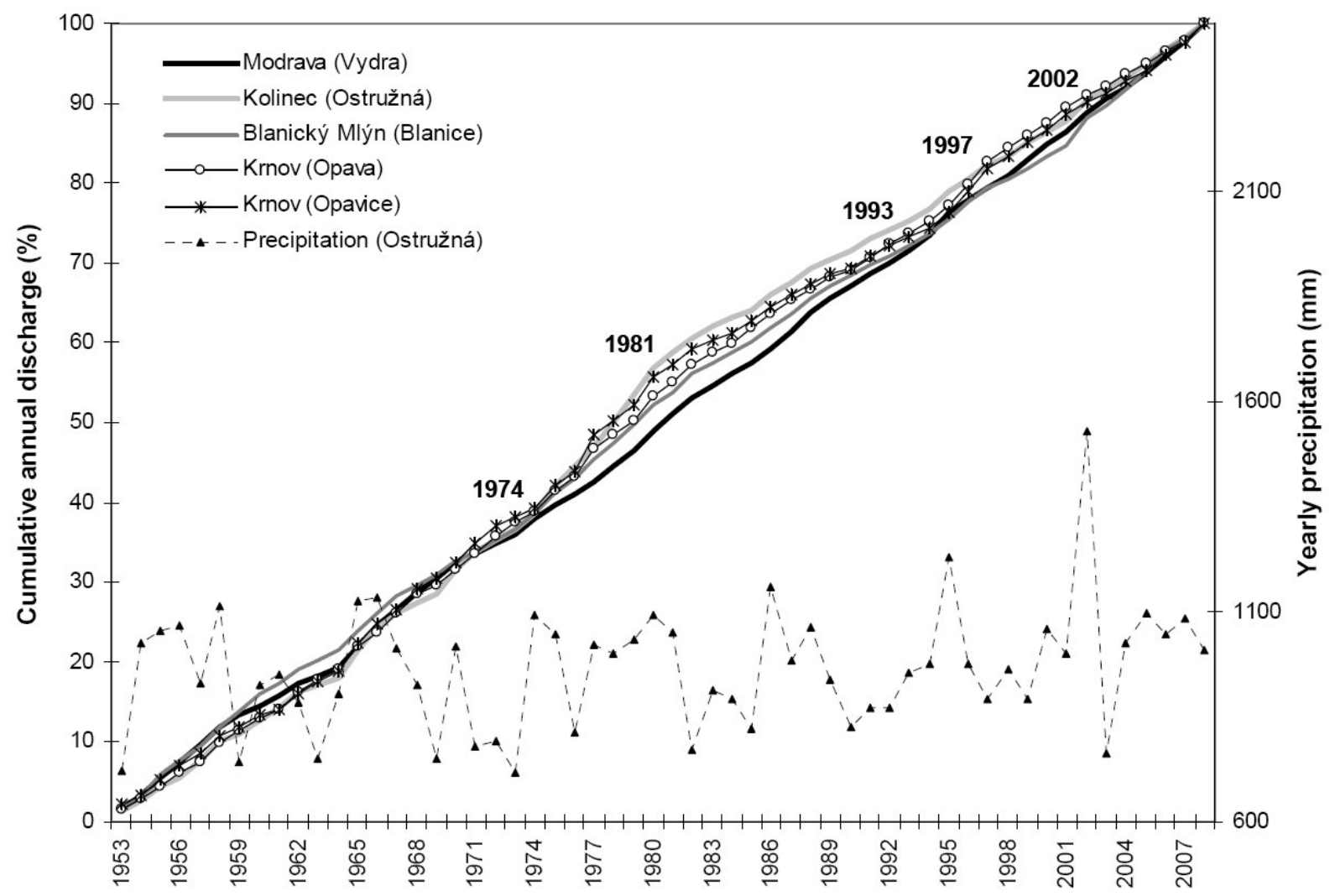

Fig. 3. Simple-mass curves of annual discharge for study basins with the course of annual precipitation in Ostružná basin (1953-2008). 


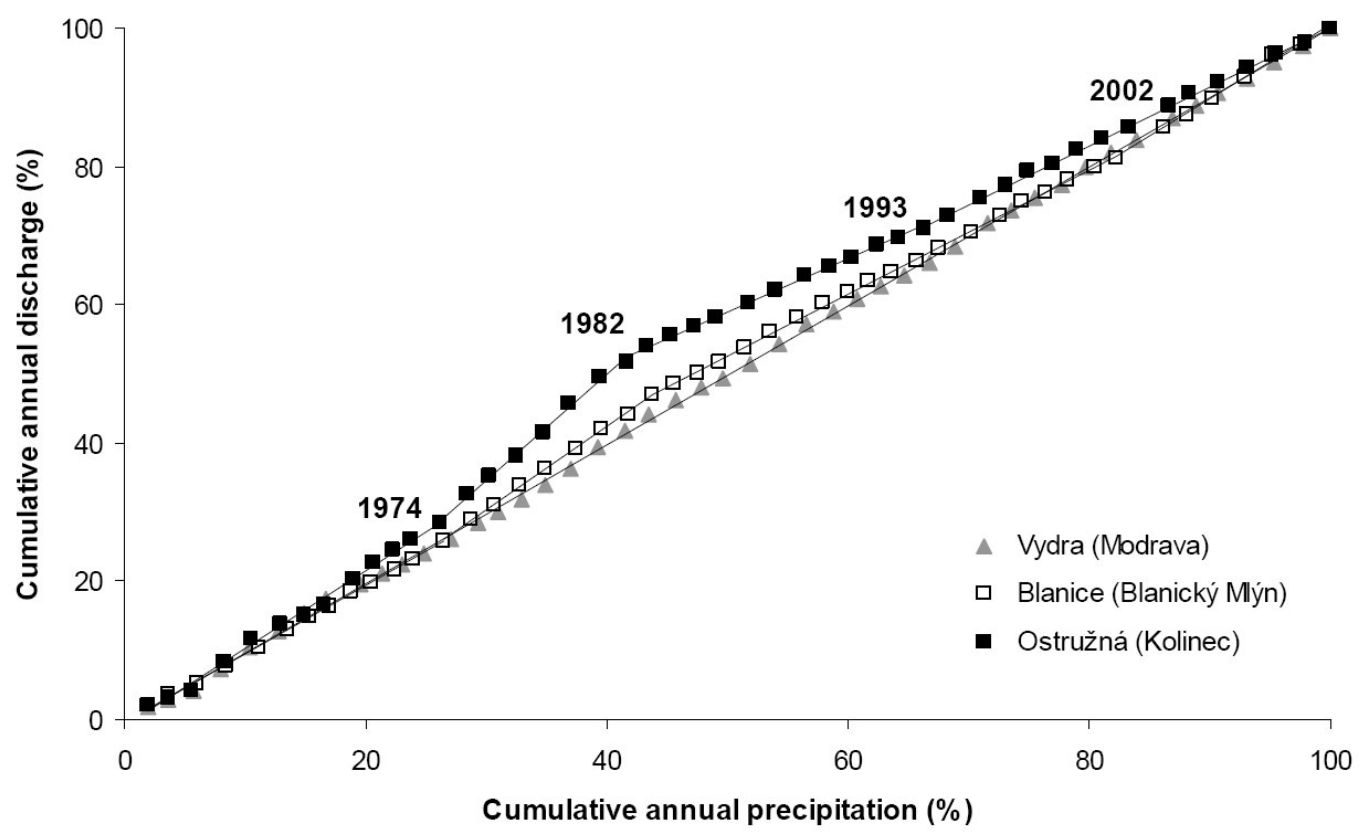

Fig. 4. Double-mass curves of annual precipitation and discharge for Vydra, Ostružná and Blanice basins (1962-2008).

\subsection{Testing of homogeneity (inhomogeneity) in time series of discharges and precipitation}

The testing of homogeneity in long-term time series is an essential step for their further analytic processing. It also contributes to the identification of significant inhomogeneity. Inhomogeneity reasons in time series might differ. Besides some systematic errors, caused by e.g. changes in ways and places of measurement, they might show changes in a particular river basin. These changes could be of anthropogenous and natural character, they might reflect a specific response to different changes, e.g. land cover, land use or climatic ones etc. Sudden "break-points" represent a typical manifestation of inhomogeneity in time series. Inhomogeneity can also be presented by long-term gradual trends. The testing methods described in the methodological part have been used for the identification and evaluation of a statistic significance of inhomogeneity in time series of discharge and precipitation data. Series of air temperature and snow cover depth data and a number of days with snow cover have been tested to support it. In the time series of mean annual discharges, there has been recorded quite significant inhomogeneity by the Pettitt test at the significance level of 0.05 in the most of the observed river basins in the year 1983 which represents certain "break-points" between hydrous and the following less hydrous period. The changes in monthly discharge time series have been detected for some streams mainly in spring and summer months $\left(Q_{5}-1998,1985, Q_{6}-1988,1981\right)$ and sometimes in winter $\left(Q_{1}-1974\right)$. Precipitation data series have proved generally high homogeneity. The relations with inhomogeneity of annual and monthly runoff data series (with the exception of the Opavice River basin in the year 1982) have not been confirmed. The identified years of changes have been tested by a Wilcoxon (Mann-Whitney) test or Kruskal-Wallis test. The interpretation of homogeneity tests (test SHNT) dealing with air temperature and snow cover data series has not been easy because the homogeneity has been observed only for particular stations. The year 1988 has been repeatedly confirmed as the year of changes. Since that year warming has become more evident. When regarding snow cover, the year 2005 appears to be influenced by a position at the end of evaluated series. The year 1988 represents secondarily maximum here. The examples of applications of homogeneity tests for discharge time series in the observed river basins are shown in Tab. 2 .

\subsection{The analysis of air temperature and snow conditions}

Air temperature and snow character are considered to be important factors influencing the development of rainfall-runoff regime. Air temperature and snow parameters have been evaluated for selected climatic stations related to the observed river 
T a b l e 2. Results of absolute homogeneity tests of discharge time series for study basins (1962-2008).

\begin{tabular}{|c|c|c|c|c|c|c|c|c|c|c|c|c|}
\hline & \multicolumn{4}{|c|}{ Vydra - Modrava } & \multicolumn{4}{|c|}{ Ostružná - Kolinec } & \multicolumn{4}{|c|}{ Blanice - Blanický Mlýn } \\
\hline & $\mathrm{P}$ & Year of change & W & $\mathrm{K}$ & $\mathrm{P}$ & Year of change & W & $\mathrm{K}$ & $\mathrm{P}$ & Year of change & $\mathrm{W}$ & $\mathrm{K}$ \\
\hline$Q_{11}$ & Yes & - & - & - & No & $1983(1975)$ & No (Yes) & No & Yes & - & - & - \\
\hline$Q_{12}$ & Yes & - & - & - & Yes & - & - & - & Yes & - & - & - \\
\hline$Q_{1}$ & No & 1974 & No & - & Yes & - & - & - & No & 1974 & No & - \\
\hline$Q_{2}$ & Yes & - & - & - & Yes & - & - & - & No & 1974 & No & - \\
\hline$Q_{3}$ & No & 1989 & No & - & Yes & - & - & - & No & 1999 & No & - \\
\hline$Q_{4}$ & Yes & - & - & - & Yes & - & - & - & Yes & - & - & - \\
\hline$Q_{5}$ & Yes & - & - & - & No & 1988 & No & - & No & 1988 & No & - \\
\hline$Q_{6}$ & No & 1981 & No & - & No & 1981 & No & - & No & 1981 & No & - \\
\hline$Q_{7}$ & Yes & - & - & - & No & $1982(1972)$ & No (Yes) & No & Yes & - & - & - \\
\hline$Q_{8}$ & Yes & - & - & - & No & 1984 & No & - & Yes & - & - & - \\
\hline$Q_{9}$ & Yes & - & - & - & No & 1981 & No & - & Yes & - & - & - \\
\hline$Q_{10}$ & Yes & - & - & - & No & $1982(1974)$ & No (Yes) & No & Yes & - & - & - \\
\hline \multirow[t]{3}{*}{$Q_{r}$} & Yes & - & - & - & No & 1983 & No & - & Yes & - & - & - \\
\hline & \multicolumn{4}{|c|}{ Opava - Krnov } & \multicolumn{4}{|c|}{ Opavice - Krnov } & \multicolumn{4}{|c|}{ Rolava - Stará Role* } \\
\hline & $\mathrm{P}$ & Year of change & $\mathrm{W}$ & $\mathrm{K}$ & $\mathrm{P}$ & Year of change & $\mathrm{W}$ & $\mathrm{K}$ & $\mathrm{P}$ & Year of change & $\mathrm{W}$ & $\mathrm{K}$ \\
\hline$Q_{11}$ & Yes & - & - & - & Yes & - & - & - & Yes & - & - & - \\
\hline$Q_{12}$ & Yes & - & - & - & Yes & - & - & - & No & 1979 & - & - \\
\hline$Q_{1}$ & Yes & - & - & - & Yes & - & - & - & Yes & - & - & - \\
\hline$Q_{2}$ & Yes & - & - & - & Yes & - & - & - & No & 1980 & No & - \\
\hline$Q_{3}$ & Yes & - & - & - & Yes & - & - & - & Yes & - & - & - \\
\hline$Q_{4}$ & Yes & - & - & - & Yes & - & - & - & No & 1989 & No & - \\
\hline$Q_{5}$ & No & 1985 & No & - & No & 1981 & No & - & No & 1985 & No & - \\
\hline$Q_{6}$ & No & 1988 & No & - & No & 1988 & No & - & No & 1988 & No & - \\
\hline$Q_{7}$ & No & 1983 & No & - & Yes & - & - & - & Yes & - & - & - \\
\hline$Q_{8}$ & Yes & - & - & - & Yes & - & - & - & Yes & - & - & - \\
\hline$Q_{9}$ & Yes & - & - & - & Yes & - & - & - & Yes & - & - & - \\
\hline$Q_{10}$ & Yes & - & - & - & No & $1982(1974)$ & No & No & Yes & - & - & - \\
\hline$Q_{r}$ & No & 1983 & No & - & No & $1983(1995)$ & No & $\mathrm{No}$ & Yes & - & - & - \\
\hline
\end{tabular}

P - Pettitt-Mann-Whitney test, W - Wilcoxon (Mann-Whitney) test, $\mathrm{K}$ - Kruskal-Wallis test, Yes - establishment of homogeneity, No - establishment of inhomogeneity, secondary year of change in the bracket, ${ }^{*}$ period 1968-2008.

basins. A total series of measurements supported by its length was the main criterion of selection. There have been involved 3 stations in the Šumava Mountains (Klatovy, Kašperské Hory and Churáňov), 4 stations in the Jeseníky Mountains (Krnov, Město Albrechtice-Žáry, Červená and Praděd) and 2 stations in the Krušné Mountains (Karlovy Vary-lázně and Fichtelberg). The river basins in the Jeseníky Mountains show lower air temperature and higher snow cover figures than the river basins in the Sumava Mountains and the Krušné Mountains at the same altitude. For a particular difference among the observed river basins, see Tab. 3 .

If we watch the development of mean air temperature in the last 50 years, a gradual increase of temperature is evident in all selected stations not regarding their altitude and geographic location. In the Fig. 5, an increase of mean annual air temperature has been recorded since the mid $80 \mathrm{~s}$ of the $20^{\text {th }}$ century. When comparing the mean annual air temperature in the period of 1961-2006 with the mean temperature in the period of 1901-1950 (Vesecký et al. 1961), the temperature varies in interval from 0.3 to $0.5^{\circ} \mathrm{C}$ (Klatovy: $+0.5^{\circ} \mathrm{C}\left(7.6 / 8.1^{\circ} \mathrm{C}\right)$, Opava: $+0.3^{\circ} \mathrm{C}\left(8.0 / 8.3^{\circ} \mathrm{C}\right)$, Krnov: $+0.3^{\circ} \mathrm{C}\left(7.8 / 8.1^{\circ} \mathrm{C}\right)$, Praděd: $\left.+0.4^{\circ} \mathrm{C}\left(0.9 / 1.3^{\circ} \mathrm{C}\right)\right)$. The most significant rises in air temperature are observed in spring and summer months, and also in winter. While the warming in the upper reaches and lower reaches of the basins is comparable in the cold half of a year, the warming is more intensive in low-lying parts during the warm half of a year. There are changes in snow cover at the same time. A number of days with snow cover has been decreasing mainly in low situated stations since the mid $80 \mathrm{~s}$ of the $20^{\text {th }}$ century (see Fig. 6.), e.g. in Klatovy there has been decreased the number of days with snow cover by almost a half compared to the period of 1920-1950. The depth of snow cover has also been decreased. The most intensive decrease has been recorded in the areas with highest altitude, which is by almost $1 \mathrm{~cm}$ per year. 
$\mathrm{T}$ a b l e 3. Mean annual air temperature and snow characteristics (1962-2008).

\begin{tabular}{lccccc}
\hline Climatic stations & $R[\mathrm{~m}]$ & $T\left[{ }^{\circ} \mathrm{C}\right]$ & $P[\mathrm{~mm}]$ & $S N[\mathrm{~cm}]$ & $S D$ (number of days) \\
\hline Krnov & 364 & 8.1 & 614 & 9 & 53 \\
Karlovy Vary & 377 & 8.1 & 627 & 2 & 52 \\
Klatovy & 430 & 8.2 & 602 & 7 & 48 \\
Žáry & 483 & 7.6 & 758 & 13 & 80 \\
Kašperské Hory & 737 & 6.3 & 832 & 15 & 88 \\
Červená & 750 & 5.7 & 750 & 28 & 114 \\
Churáňov & 1118 & 4.5 & 1105 & 40 & 147 \\
Fichtelberg & 1213 & 3.2 & 1126 & 66 & 173 \\
Praděd* & 1490 & 1.1 & 1134 & 87 & 175 \\
\hline
\end{tabular}

$R$ - high-level altitude, $T$ - mean annual air temperature, $P$ - mean annual precipitation amount, $S N$ - mean annual snow cover depth, $S D$ - mean number of days with snow cover, *) period 1962-1997.

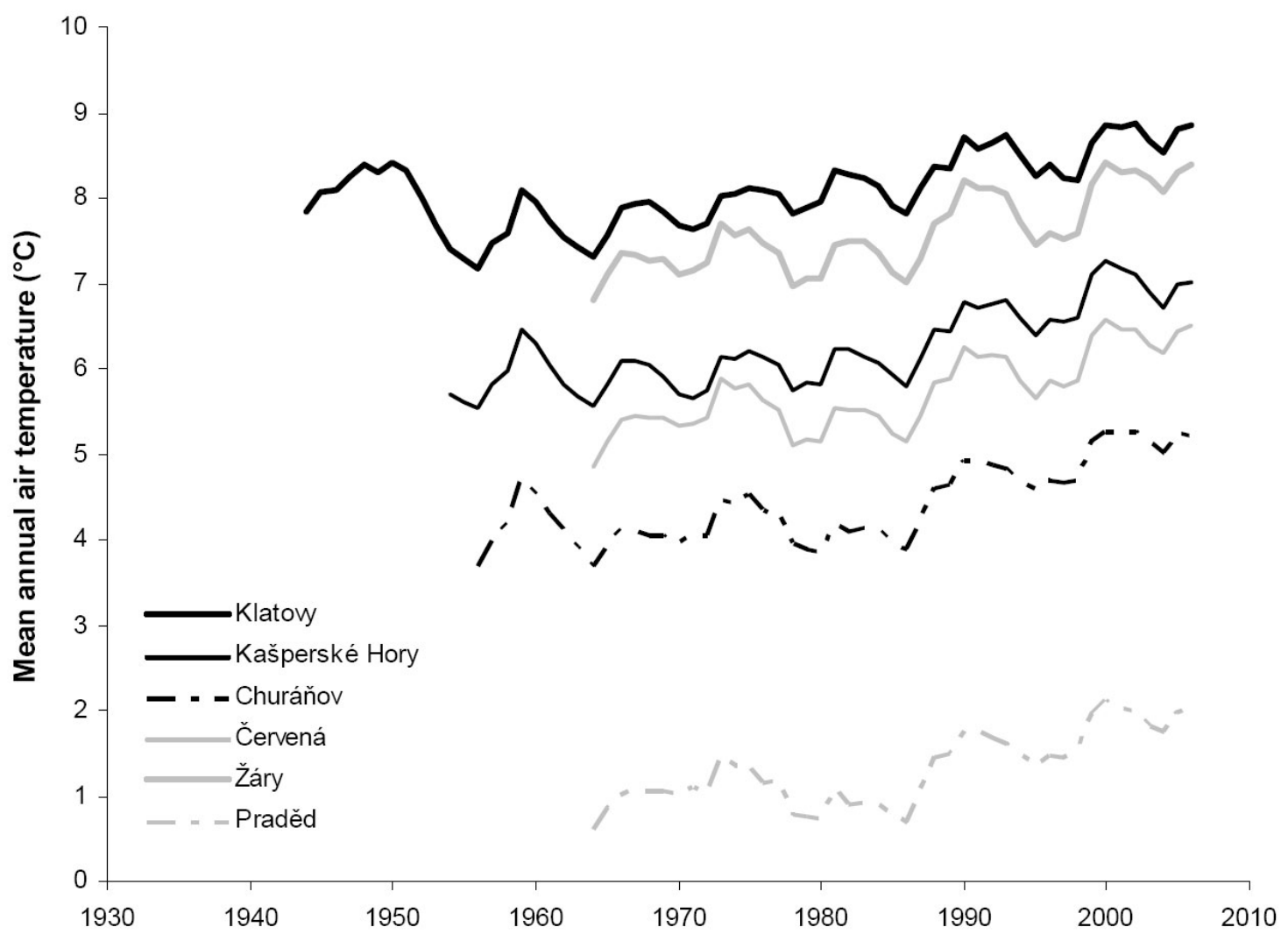

Fig. 5. Development of mean air temperature for selected climatic station, 5-year moving averages (1942-2008). Praděd station finished observations in the year 1997, the data has been calculated as a multiple regression using the data of neighbouring climatic stations.

\subsection{Analysis of high water-level events}

A frequency analysis of higher water-level events has been given in the context with the results of mass curves of mean runoff characteristics and identified significant inhomogeneity. Discharges higher than one-year water-level have been considered. For results see Fig. 7, where there are chronologically shown each highest recorded daily dis- charges in a selected period of time together with the frequency of one-year and higher water-level events of all river in a total sum. It is evident that in the hydrous period of $1974-1982$, which was reflected almost in all of the observed river basins, there was recorded a certain higher number of oneyear or higher flood events (but less than 5-year flood event) at the end of this period. More flood events occurred only in the river basins of the 


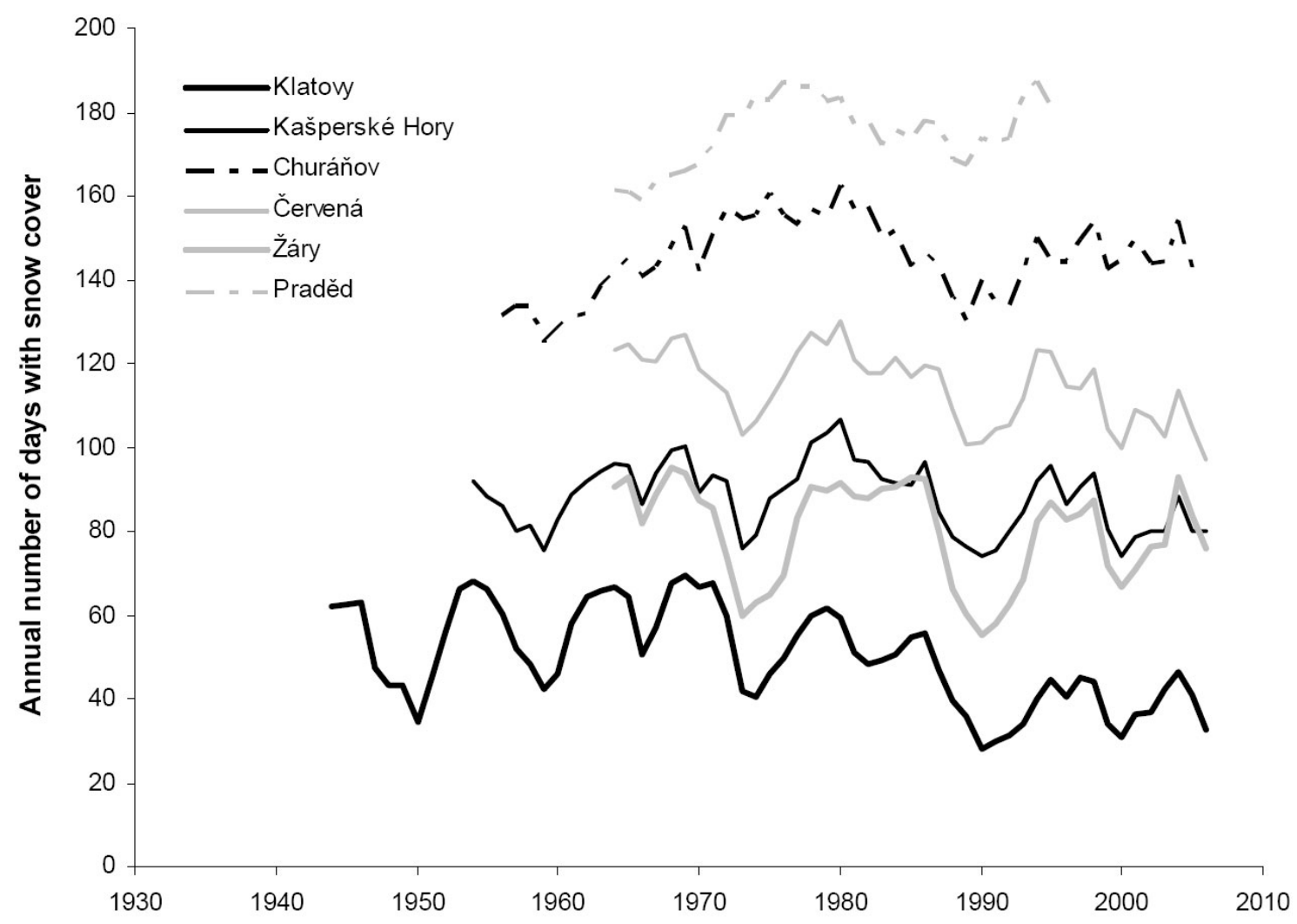

Fig. 6. Development of number of snow cover days for selected climatic station, 5-year moving averages (1942-2008). Praděd station finished observations in the year 1997.

Opavice $(1975,1977)$ and the Opava Rivers (1977), at the level of 5- to 10-year flood events. There is no flood occurrence in the Šmava basins at this time period. This implies that the identified period of increasing runoff cannot be satisfactorily explained only as a high flood event occurrence. Mass curves provide the clear evidence of the fact that the highest recorded floods caused short-term deviations from the linear course. The floods of this period that reflect the trend occurred in the Opava and Opavice rivers in 1997 and in the Blanice in 2002, corresponding with more than a cent-year flood event at their culmination points.

\subsection{Trend analysis using statistic testing methods}

The identification of a trend in time series is important from the viewpoint of forecasting of an observed quantity. A seasonal Mann-Kendall test was used as a basic method. It was applied in monthly and annual time series of discharges and surface area precipitation in the observed basins. It also tested series of precipitation totals, air temperature and snow parameters for ombrometric and climatic stations related to the particular basins for the hydrological period of 1962-2008. The significance of a trend was tested at the level of 0.05 . The main results have been recorded in the Tabs. 4 and 5. Significant trends of decreasing runoff in spring and summer months have been identified by this test. While the significant decrease was recorded only in June for the Vydra River, there were more such records in May, June and July for most of the observed rivers. The same trend was proved in $\mathrm{Au}-$ gust and September for the Ostružná River. On the contrary to this, a significant runoff increase was recorded in winter months (February and mainly March), particularly in the Sumava River basins (Blanice and Vydra) and in the Rolava catchment. No evidence of winter trend has been recorded in the area of the Jeseníky Mountains. The trends have not been proved in the time series of mean annual discharges. There have not been identified such proving trends for monthly surface area precipitation totals as for discharges. Despite this fact, a certain increase in precipitation is noticeable in the Šmava River basins and in the Rolava basin in winter season, especially in January, February and 


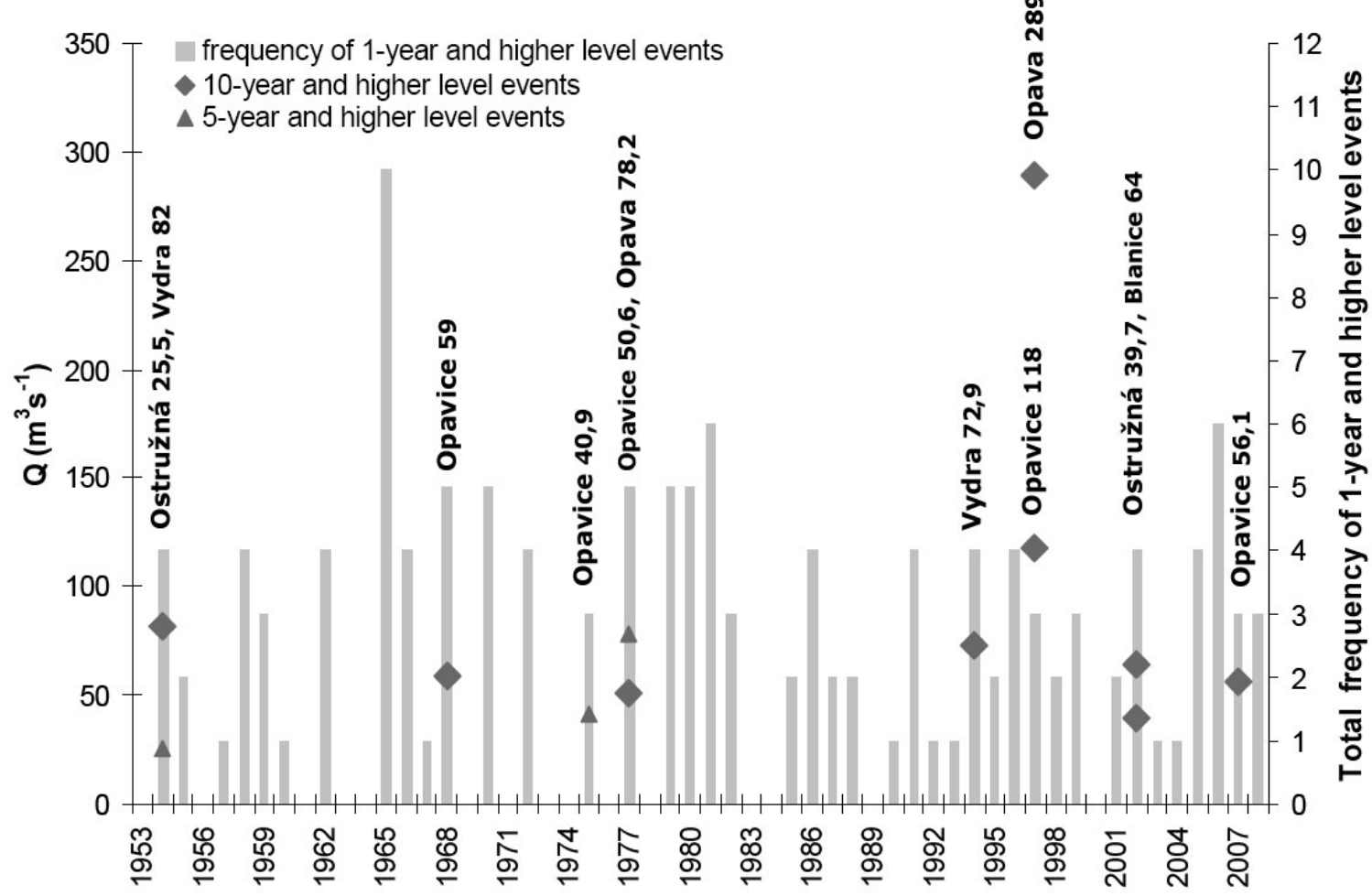

Fig. 7. Frequency of high water-level events study basins (1953-2008).

March. Decrease in the volume of precipitation does not appear to be significant in May and June, except for the Vydra River. Particular precipitation increase in the Šmava River basins and in the Rolava basin is noticeable in the time series of annual precipitation totals, the opposite trend or no trend has been observed in the river basins of Opava and Opavice. It has always been interesting to observe the spatial distribution of the trend of precipitation totals according to individual ombrometric stations (see Fig. 8). In the western part of the Jeseníky Mountains there have been proved increasing trends in the cold half of a year, but in the eastern part there has been proved a decreasing tendency in the course of annual precipitation.

The most significant statistic trends have been proved in the time series of mean air temperature, both monthly and annual figures, in the period of last 50 years. A significant increase of mean annual air temperature can be observed in all of the included stations not regarding their altitude and geographic location. The most remarkable increase covers the period from April to August (with highest values in May and August) and also the winter season, with highest values in December and January. The identifications of trends in time series of snow characteristics appears to be difficult to find because there are fewer evaluated cases, discontinues and changeable character of snow cover. In the evaluated time series there is rather a decrease in snow cover, which has resulted in a decrease of mean snow cover depth (higher altitude stations) and decrease of the number of days with regular snow cover (lower altitude stations).

Expected causal relations among hydroclimatic elements have been tested here besides testing of homogeneity and trends in time series. Some important positive and negative correlations of basic hydroclimatic elements have been confirmed with the support of Kendall coefficient of sequential correlation $\tau$. The positive correlations have appeared between precipitation and discharge mainly in the warm half of a year, between the snow cover depth and discharge in the cold half of a year, between the snow cover depth and precipitation mainly for stations of higher altitude, and then the negative correlations between the duration of snow cover and air temperature. Less significant direct relations have been revealed between discharge and air temperature, negative correlation in warm half of a year and positive in the cold one. 
$\mathrm{T} \mathrm{a} \mathrm{b} 1 \mathrm{e}$ 4. Long-term trends in mean discharge and precipitation monthly and annually time series for study basins (1962-2008).

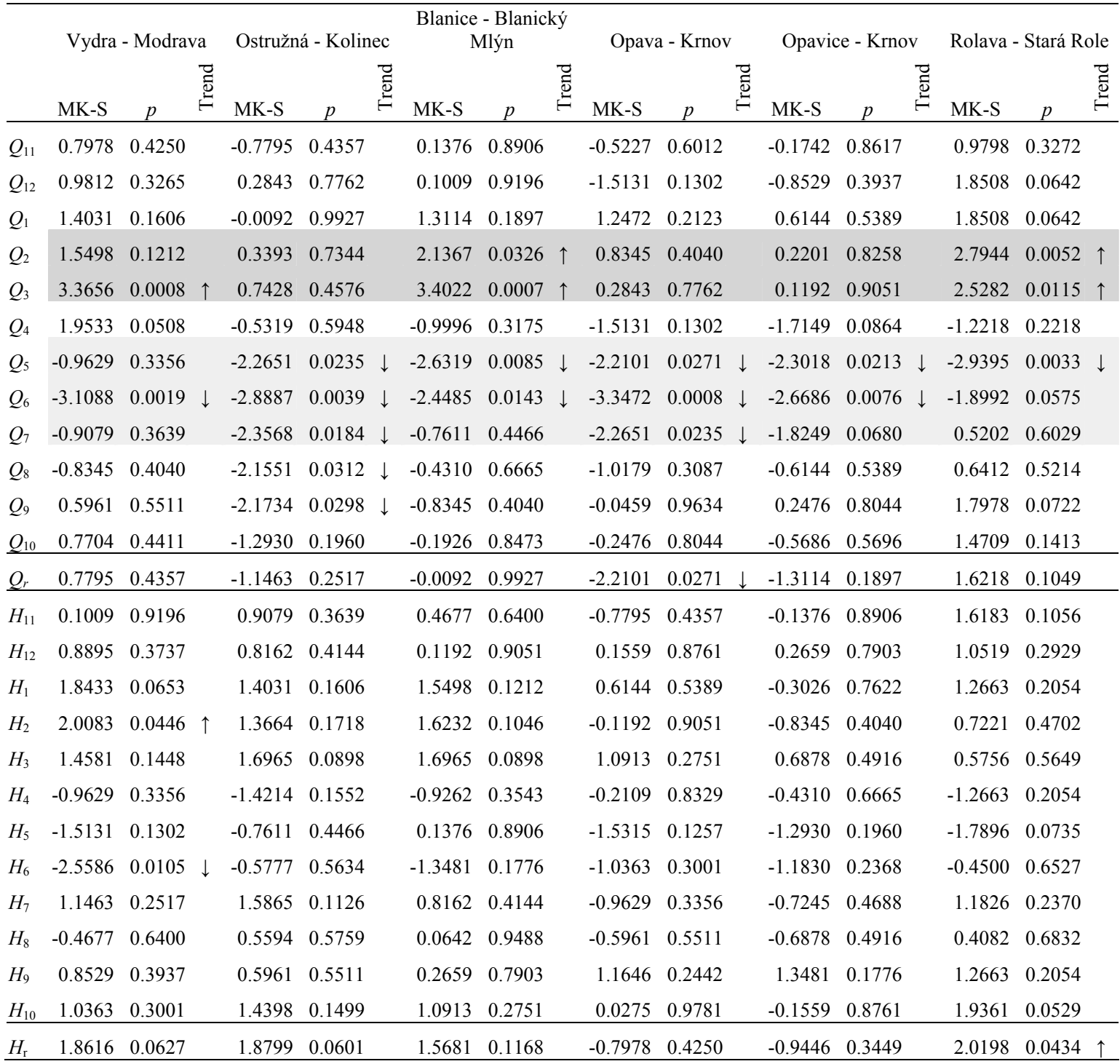

$Q$ - discharge, $H$ - precipitation amount for a basin, MK-S - Mann-Kendall statistics, $p$ - statistical significance, $\uparrow-$ rising trend, $\downarrow$ - decreasing trend.

\section{Conclusion}

This work deals with an analysis of runoff time series and selected climatic characteristics in headwater areas of the Šumava Mountains, the Jeseníky Mountains and the Krušné Mountains in the last 50 years. In the results, which have been influenced mainly by the quality and length of time series, there are also reflected some findings influenced by uneven conditions of the observed river basins, particularly by geographic location, altitude and variations in land use and land cover. Despite the fact it is possible to prove certain deviations and trends which are similar to each other in the ob- served areas. The identification of increased mean discharges for the period of time 1974-1982 has been identified in all of the observed streams, except for the Vydra River. It is evident that the deviation in the run-off has been more noticeable in low lying areas as well as in the areas of less afforestation and with a more significant anthropogenous influence. Strong links are to be found in the development of climate; especially in higher figures of relatively equally spread precipitation, then also in a higher snow cover depth together with moderate character of winters and finally in relatively low air temperature in summers (see Fig. 9). A connection to the significant amelioration interferences 


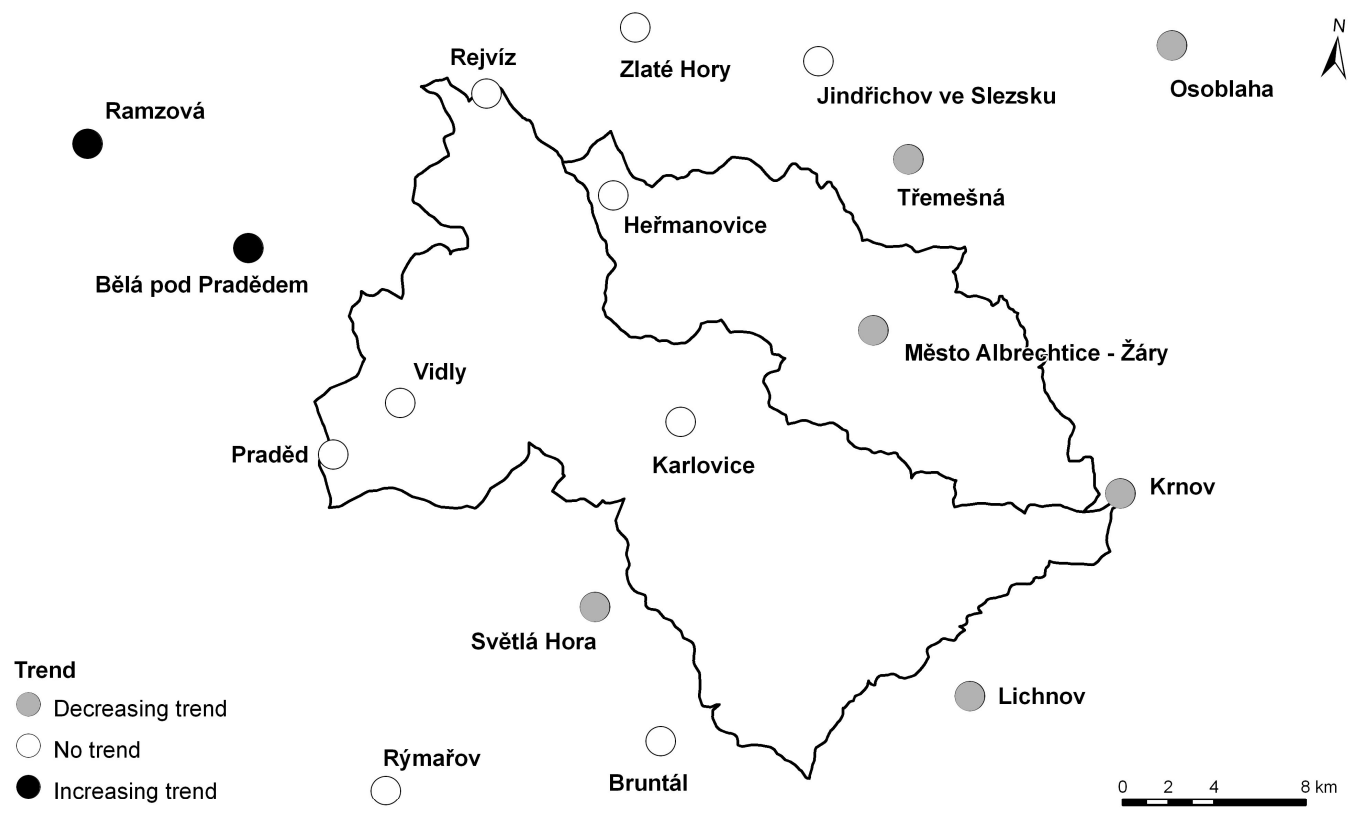

Fig. 8. Long-term trend of precipitation amount for selected climatic stations in Jeseníky Mountains (1962-2008).

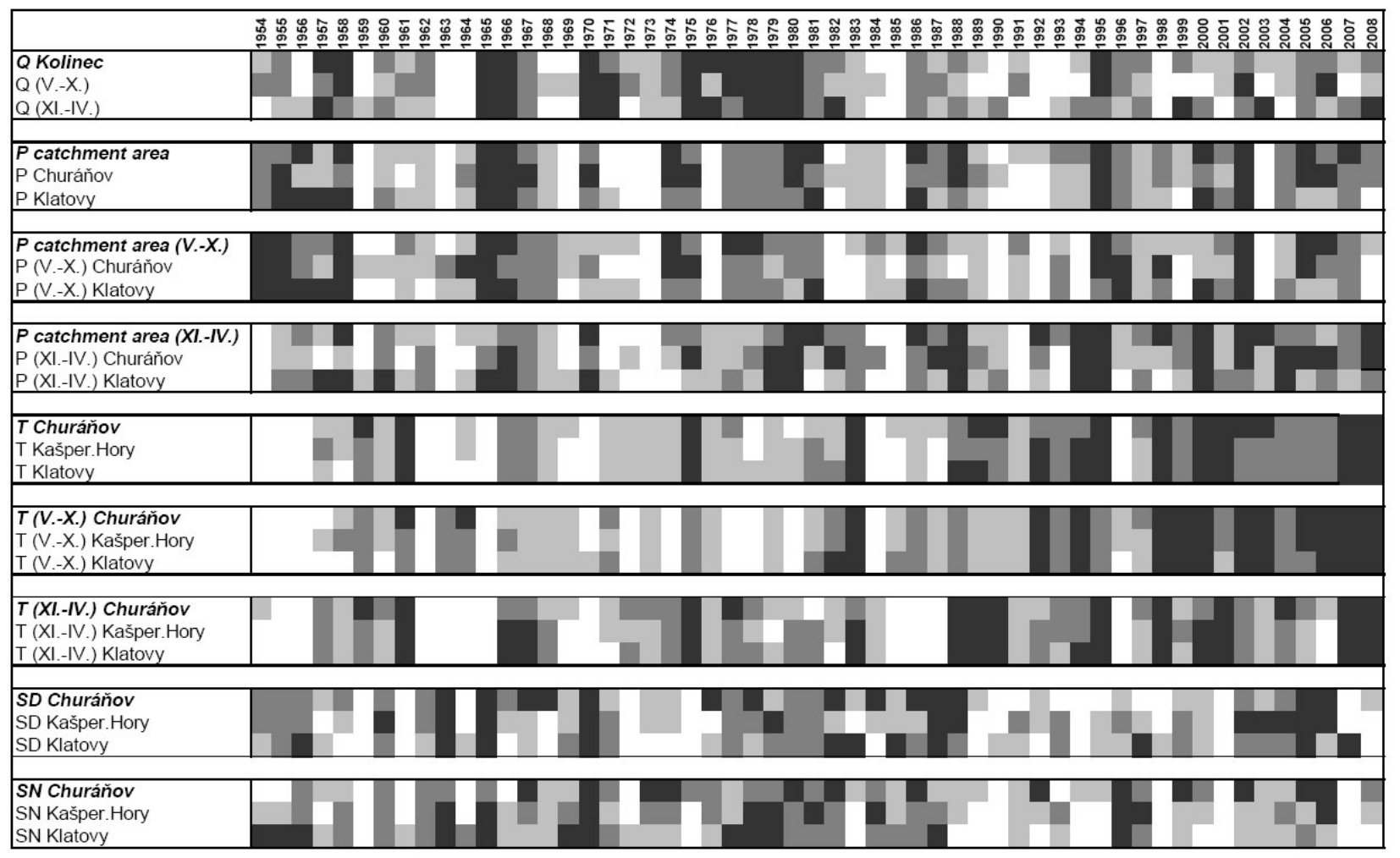

Fig. 9. Development of discharge and climate characteristics in the Ostružná basin (1954-2008); $Q-$ mean discharge, $P$ - precipitation amount, $T$ - mean air temperature, $S D$ - mean snow cover depth, $S N$ - number of days with snow cover. Black colour areas: values $>$ upper quartile, gray dark: $<$ upper quartile, median $>$, grey light: $<$ median, lower quartile $>$, white: $<$ lower quartile. 
from $70 \mathrm{~s}$ and $80 \mathrm{~s}$ of the $20^{\text {th }}$ century is probably random.

The following period (since the year 1982) till present time, except for the catastrophic floods in 1997 and 2002, has proved a successive decrease in runoff. Deviations in the runoff have been statistically verified by different statistical tests, mainly by Pettit-Mann-Whitney test, Mann-Whitney test and Kruskal-Wallis test. In the time series of mean annual discharges for the most of the selected rivers, significant inhomogeneity has been identified for the year 1983 which represents a certain breakpoint between hydrous and the following less hydrous period. In the series of surface area precipitations, no significant inhomogeneity has been recognized. The testing of homogeneity of the time series of air temperature and snow parameters have been done by SNHT test (Standard Normal Homogeneity Test). An interpretation of the gained knowledge is not easy. In some climatic stations, the year of change (1988) has repeatedly been confirmed. Since this year warming has been more evident.

An identification of hydro-climatologic time series trends, done by the seasonal Mann-Kendall test, shows a very significant result. In May and June an important runoff decrease has been confirmed in all of the observed streams. No direct link of statistical importance with a rainfall decrease in the mentioned months has been proved. A significant increase in runoff during winter months has been recorded in the Rolava River and in the Šumava Rivers as well. This trend can be associated not only with the globally rising air temperature, but also with increasing amount of winter precipitation in these areas. The similar phenomenon has not been proved in the Opava and the Opavice River basins. Different trends in the development of precipitations in the western and eastern parts of the Jeseníky Mountains could be linked with changes in circulation. The trends of statistic importance, not regarding altitude and geographical position, have been proved in the air temperature series. Warming is the most significant in the periods from April to August and from December to January. During summer months higher temperature can intensify the process of evapotranspiration. The decrease in runoff and insufficient supplies of ground water are associated with the trends in snow cover. A decreasing snow cover depth and the number of days with snow cover are important especially in low lying climatic stations.
Results are usable in the water management planning. Significant decrease of runoff in the beginning of the summer period without direct connection to decrease of precipitation, increase of runoff in the winter months, both linked by annual increase of air temperature and shortage of snow cover will lay stress on retention measures in headwater areas.

Acknowledgements. This research was realized under the framework of the research plan MSM 0021620831 "Geographical systems and risk processes in the context of global changes and European integration" and the research project $\mathrm{VaV}$ $\mathrm{SM} / 2 / 57 / 05$ "Long-term changes of river ecosystems in floodplains affected by extreme floods".

\section{REFERENCES}

ANDĚL J., 1998: Statistické metody. Matfyzpress. Praha.

BAE D. a kol., 2008: Long-term trend of precipitation and runoff in Korean river basis. Hydrol. Process, 22, 14, 2644 $-2656$.

BIČÍK I. a kol., 2003: Vývoj struktury ploch v povodí Otavy. In: Hodnocení vlivu změn př́rodního prostředí na vznik a vývoj povodní (ed. Langhammer). PřF UK, Praha.

BIRSAN M.V. a kol., 2005: Streamflow trends in Switzerland. J. Hydrol., 314, 1-4, 312-329.

BLAŽKOVÁ Š., KOLÁŘOVÁ S., 1994: Vliv odlesnění na hydrologický režim v oblasti Jizerských hor. Výzkum pro praxi, 28, VÚV T.G. Masaryka, Praha.

BURN D.H. a kol., 2004: Hydrological trends and variability in the Liard River basin. Hydrol. Sci. J., 49, 1, 53-68.

CAHYNOVÁ M., HUTH R., 2007: Trendy v kalendáři povětrnostních situací HMÚ/ČHMÚ v období 1946-2002. Meteorologické zprávy, 60, 6, 175-182.

CORINE, 2000: Databáze Corine Land cover, MŽP.

CZAJA, S., 2005: Changes in river discharge structure and regime in mining-industrial-urban areas. Reg. Environ. Change., 5, 18-26.

DOMONOKOS, P., PIOTROWICZ, K., 1998: Winter temperature characteristics in Central Europe. Int. J. Climatol., $18,1405-1417$.

HELSEL D. R., FRANS L. M, 2006: Regional Kendall Test for Trend. Environ. Sci. Technol., 40, 13.

DOLEŽAL F. a kol., 2004: Bilanční odhady příspěvku odvodňovacích soustav k průběhu povodní. Výzkumná zpráva, VÚMOP, Praha.

FALARZ, M., 2004: Variability and trends in duration and depth of snow cover in Poland in the 20th century. Int. J. Climatol., 24, 1713-1727.

FIALA T., 2008: Statistical characteristics and trends of mean annual and monthly discharges of Czech Rivers in the period 1961-2005. J. Hydrol. Hydromech., 56, 2, 133-140.

FRANKE, J., GOLDBERG, V., EICHELMANN, U., FREYDANK, E., BERNHOFER, C., 2004: Statistical analysis of regional climate trends in Saxony, Germany. Clim. Res., 27, $145-150$.

FU G. a kol., 2004: Hydro-climatic trends of the Yellow River basin for the last 50 years. Clim. Change, 65, 149-178. 
HAIS M., 2003: Vývoj a změny land coveru v povodí Otavy za posledních 15 let. In: Hodnocení vlivu změn prírodního prostředí na vznik a vývoj povodní (ed. Langhammer). PřF UK, Praha.

HINTNAUS I., 2008: Změny ve vývoji krajiny v pramenné oblasti Blanice. [Bakalářská práce.] PřF UK, Praha.

HUANG M. a kol., 2003: Runoff response to afforestation in a watershed of the Loess Plateau, China. Hydrol. Process, $17,13,2599-2609$.

HUO Z. a kol., 2008: Effects of climate changes and waterrelated human activities on annual stream flows of the Shiyang river basin in arid north-west China. Hydrol. Process, 22, 16, 3155-3167.

CHAVES J. a kol., 2008: Land management impacts on runoff sources in small Amazon watersheds. Hydrol. Process., 22, 12, 1766-1775.

CHEN H., 2007: Historical temporal trends of hydro-climatic variables and runoff response to climate variability and their relevance in water resource management in the Hanjiang basin. J. Hydrol., 344, 3-4, 171-184.

JUCKEM P.F. a kol., 2008: Effects of climate and land management change on streamflow in the driftless area of Wisconsin. J. Hydrol., 355, 1-4, 123-130.

KALVOVÁ J. a kol., 2002: Globální klimatické modely a scénáře změny klimatu pro Českou republiku. In: Národní klimatický program České republiky, 32, Praha, 1-58.

KAŇOK J., 1997: Antropogenní ovlivnění velikosti průtoků řek povodí Odry po profil Koźle. Spisy prací Př́rodovědecké fakulty Ostravské univerzity, 103, Ostravská univerzita, Ostrava.

KENDALL M.G., 1975: Rank correlation methods. Charles Griffin, London.

KLIMENT Z., MATOUŠKOVÁ M., 2005: Trendy ve vývoji odtoku v povodí Otavy. Geografie, 110, 1, 32-45.

KLIMENT Z., MATOUŠKOVẢ M., 2006: Changes of runoff regime according to human impact on the landscape. Geografie, 111, 3, 292-304.

KLIMENT Z., MATOUŠKOVÁ M., 2008: Long-term Trends of Rainfall and Runoff Regime in Upper Otava River Basin. Soil and Water Research, 3, 3, 155-167.

KLIMENT Z., MATOUŠKOVÁ M., 2009: Runoff changes in the Šumava Mountains (Bohemian Forest) and the foothill regions: Extent of influence by human impact and climate changes. Water Resour. Managmnt., 23, 1813-1834.

KLÖCKING B., HABERLANDT U., 2002: Impact of landuse changes on water dynamics - a case study in teperate meso and macroscale river basin. Physics and Chemistry of the Earth, 27, 619-629.

KRÁLOVEC V., 2009: Změny srážkoodtokových poměrů v povodí horní Opavy. [Diplomová práce.] PřF UK, Praha.

KUBÁT J., 2007: Dopady klimatických změn na hydrologický režim v České republice. [Online, cit. 2009-03-06]. Available: http://www.chmi.cz/katastrofy/kubat1607.pdf

KUNDZEWICZ Z., ROBSON A., 2004: Change detection in hydrological records - a review of the methodology. Hydrol. Sci. J., 49, 1, 7-20.

KŘÍŽ V., 2003: Změny a zvláštnosti vodního režimu řeky Ostravice. Geografie, 108, 1, 36-48.
LEDVINKA O., 2008: Trendy srážkoodtokového režimu v povodí Rolavy. [Diplomová práce.] PřF UK, Praha.

LIBISELLER C., 2004: MULTMK/PARTMK. A program for computation of multivariate and partial Mann-Kendall test. LIU. Linköping.

MA X. et al., 2009: Response of hydrological processes to land-cover and climate changes in Kejie watershed, southwest China. Hydrol. Process., 23, 1179-1191.

MAJERČÁKOVÁ, O., ŠKODA, P., DANÁČOVÁ, Z., 2007: Vývoj vybraných hydrologických a zrážkových charakteristík za obdobia 1961-2000 a 2001-2006 v oblasti Vysokých Tatier. Meteorol. Čas., 10, 4, 205-210.

MANN H.B., 1945: Nonparametric test against trend. Econometrica, 13, 245-259.

MEYER W.B., 2001: Human impact on the Earth. Cambridge University Press, Cambridge.

PEKÁROVÁ P., 2003: Identifikácia dlhodobých trendov a fluktuácií hydrologických radov. Čast' II. Výsledky. J. Hydrol. Hydromech., 51, 2, 97-108.

PEKÁROVÁ, P., MIKLÁNEK, P., PEKÁR, J., OLBŘÍMEK, J., 2008: Analýza zmien štatistických charakteristík denných úhrnov zrážok na stanici Hurbanovo v rôznych obdobiach. Čast' I. Viacročná variabilita a spektrálna analýza. Acta Hydrol. Slovaca, 9, 1, 64-76.

SAMANIEGO L., BÁRDOSSY A., 2005: Robust parametric models of runoff characteristics at the mesoscale. J. Hydrol., 303, 136-150.

SEARCY J.K., HARDISON CH., 1960: Double-Mass Curves. Manual of Hydrology: Part 1 General Surface-Water Techniques. Geological Survey Water-Supply Paper 1541 - B. U.S. Department of Interior.

SCHÖNER, W., AUER, I., BÖHM, R., 2009: Long term trends of snow depth at Sonnblick (Austrial Alps) and its relation to climate change. Hydrol. Process., 23, 1052-1063.

ŠTĚPÁNEK P., 2004: Homogenizace teploty vzduchu na území České republiky v období přistrojových pozorování. Práce a studie, 32, ČHMÚ, Praha.

ŠERCL P., LETT P., 2004: Výpočet rastru srážek v prostředí GIS. Uživatelská příručka. ČHMÚ, Praha.

ŠVIHLA V. a kol., 1992: Výzkumný objekt Ovesná Lhota. VÚMOP, Praha.

TRÖMEL, S., SCHÖNWIESE, C. D., 2008: Robust trend estimation of observed German precipitation. Theor. Appl. Climatol., 93, 107-115.

VESECKÝ A. a kol., 1961: Podnebí Československé socialistické republiky. Tabulky. ČHMÚ, Praha.

WU W. et al., 2007: Modelling the impact of recent land-cover changes on the stream flows in northeastern Puerto Rico. Hydrol. Process, 21, 21, 2944-2956.

ZHANG X. a kol, 2008: Response of streamflow to changes in climate and land use/cover in the Loess Plateau, China. Water. Resour. Res., 44, doi:10.1029/2007WR006711.

Received 29 January 2010 Accepted 23 June 2010 